Research article

\title{
Species diversity, population structure and regeneration status of woody species on Yerer Mountain Forest, Central Highlands of Ethiopia
}

\author{
Nesibu Yahya*, Belay Gebre and Genene Tesfaye \\ Ethiopian Environment and Forest Research Institute, Central Ethiopia Environment and Forest Research \\ Center, Ecosystem management directorate, PO Box: 30708, Addis Ababa, Ethiopia
}

*Corresponding Author: sof.swt@gmail.com

[Accepted: 23 July 2019]

\begin{abstract}
Yerer Mountain forest is one of the few remaining dry Afromontane forests found in the central highlands of Ethiopia. Information on woody species composition, diversity and regeneration status in the aforementioned forest are lacking. The study, therefore, aims to study the diversity, population structure and regeneration status of woody species in the Forest of Yerer Mountain. Data were collected using 36 main plots of size $20 \mathrm{~m} \times 20 \mathrm{~m}$ for tree/shrub. Two $5 \mathrm{~m} \times$ $5 \mathrm{~m}$ (opposite corner) and five $2 \mathrm{~m} \times 2 \mathrm{~m}$ (four at the corner and one at the center) subplots were established in the main plot sapling and seedling, respectively. DBH, height of trees and environmental data (altitude, latitude, longitude, aspect and slope) were recorded. Thirty-one indigenous woody species that belong to 23 families were observed. The Shannon-Wiener diversity indices of woody species in the study sites were 2.0, 2.14 and 2.38 in the higher, middle and lower altitude, respectively. The density of seedling, sapling, shrubs and trees were 6383, 1022,481 and $115 \mathrm{ha}^{-1}$, respectively. Seven woody species (Juniperus procera, Pittosporum abyssinicum, Buddleja polystachya, Rhus retinorrhoea, Croton macrostachyus, Prunus africana and Acacia bussei) dominated the forest while Juniperus procera is the most dominated one (95 $\%$ ). The structural analyses of the whole community of the study area shows a reverse "J" shape pattern, which indicate healthy regeneration status of woody species. However, the population structure of the aforementioned dominant species exhibited unhealthy structure. The study concluded that the forest is diverse, however, dominated by small-sized tree/shrub species that is under early stage of succession after disturbance. Therefore, intervention of forest management practices to enhance its diversity and natural regeneration is needed.
\end{abstract}

Keywords: Evenness - Frequency - Important value index - Richness.

[Cite as: Yahya N, Gebre B \& Tesfaye G (2019) Species diversity, population structure and regeneration status of woody species on Yerer Mountain Forest, Central Highlands of Ethiopia. Tropical Plant Research 6(2): 206213]

\section{INTRODUCTION}

Ethiopia has diverse environmental and climatic conditions that have contributed to the formation of diverse ecosystems. This resulted in diverse flora and fauna. This is due to variation from the highest peak Ras Dashen (4620 $\mathrm{m}$ above sea level) down to the Afar depression (110 m below sea level) (EFAP 1994). As a result, the country is considered as one of the most important among 25 centre of biodiversity in the world (EFAP 1994, Woldu et al. 2002, Senbeta \& Denich 2006). Afro-alpine, Montane forest, Desert woodland, Montane grassland, Aquatic and Wetland are among the major natural ecosystems in the country.

However, woody species in forest ecosystem are being destroyed at an alarming rate due to deforestation as a result of over population growth (Amsalu et al. 2007, Kibret et al. 2012, Melaku et al. 2012, Bewket \& Abebe 2013, Kindu et al. 2013, Meshesha et al. 2013, Mishra et al. 2013). This is due to forest clearing for agricultural expansion, overgrazing, extraction of woody species for energy source and construction materials (Senbeta \& Teketay 2003, Soromessa et al. 2004). This resulted in forest degradation and land degradation in the country. As a result, due to loss of forest ecosystem, biodiversity resources along with their habitats are rapidly 
disappearing in the country (Teketay 1992, Woldemariam \& Teketay 2001, Woldemariam 2003, Senbeta \& Denich 2006). Therefore, science-based knowledge and strong policy should support the proper planning and implementation of sustainable forest management to address environmental challenges.

Therefore, continuous assessment on diversity and structural analysis are essential to provide baseline information regarding forest ecology (Giriraj et al. 2008, Pappoe et al. 2010). Understanding of the diversity and structure of the forest are also useful in identifying ecologically and economically important plants species (Addo-Fordjour et al. 2009). Information on population structure can provide an insight whether a particular population in the forest has a stable distribution or not (Tesfaye et al. 2010).

Yerer mountain forest is one of a ruminant dry-evergreen montane forest. The area experienced unregulated extraction of wood and non-wood forest products as it is near to the capital Addis Abeba. Ultimately, such unregulated extraction will affect the existed plant diversity and lead to floral species loss. This being the situation, very little is known about Yerer mountain forest in general and its floral diversity in particular. Several studies on population structure and diversity have been conducted at various forest community types of Ethiopia such as Zegie peninsula, Tara Gedam and Abebaye, Kinphee forest, Island of Lake Zeway, Borana southern Ethiopia (Senbeta \& Teketay 2003, Zegeye et al. 2006, Alelign et al. 2007, Zegeye et al. 2011, Worku et al. 2012). However, knowledge on the diversity, population structure and regeneration of woody species is still scanty for Yerer Mountain forest. Such knowledge and information is critical to document floral resources of the country and to implement sustainable management of forest. Thus, this study was investigated to provide quantitative information on the species richness, diversity, evenness population structure and status of regeneration of woody species in the study area.

\section{MATERIALS AND METHODS}

Study area

The study was carried out on the Yerer Mountain, Oromia Regional State, East Shewa Zone (Fig. 1). The area located $\left(8^{\circ} 52^{\prime}\right.$ to $8^{\circ} 55^{\prime} \mathrm{N}$ and $38^{\circ} 58^{\prime}$ to $\left.38^{\circ} 59^{\prime} \mathrm{E}\right) 40 \mathrm{~km}$ Southeast of Addis Ababa with altitude ranges from 2100 to $3000 \mathrm{~m}$. The total area of Yerer forest is 6,000 hectares, of which 3,500 hectares are designated as a forest area, which is under the management of Oromia Forest and Wildlife Enterprise (OFWE).

The study site has received with an average rainfall of $1000 \mathrm{~mm}$ per annum and with average minimum and maximum temperatures of $10^{\circ} \mathrm{C}$ and $26^{\circ} \mathrm{C}$, respectively (ENMSA 2011). It has a unimodal rainfall nature. The studied forest is classified as dry-evergreen montane forest, Afroalpine and Sub-afroalpine ecosystem and composed from both natural and plantation forest (Friis et al. 2010). The dominant plantation tree species are Eucalyptus globulus Labill., Eucalyptus camaldulensis Dehnh. and Cupressus lusitanica Mill.

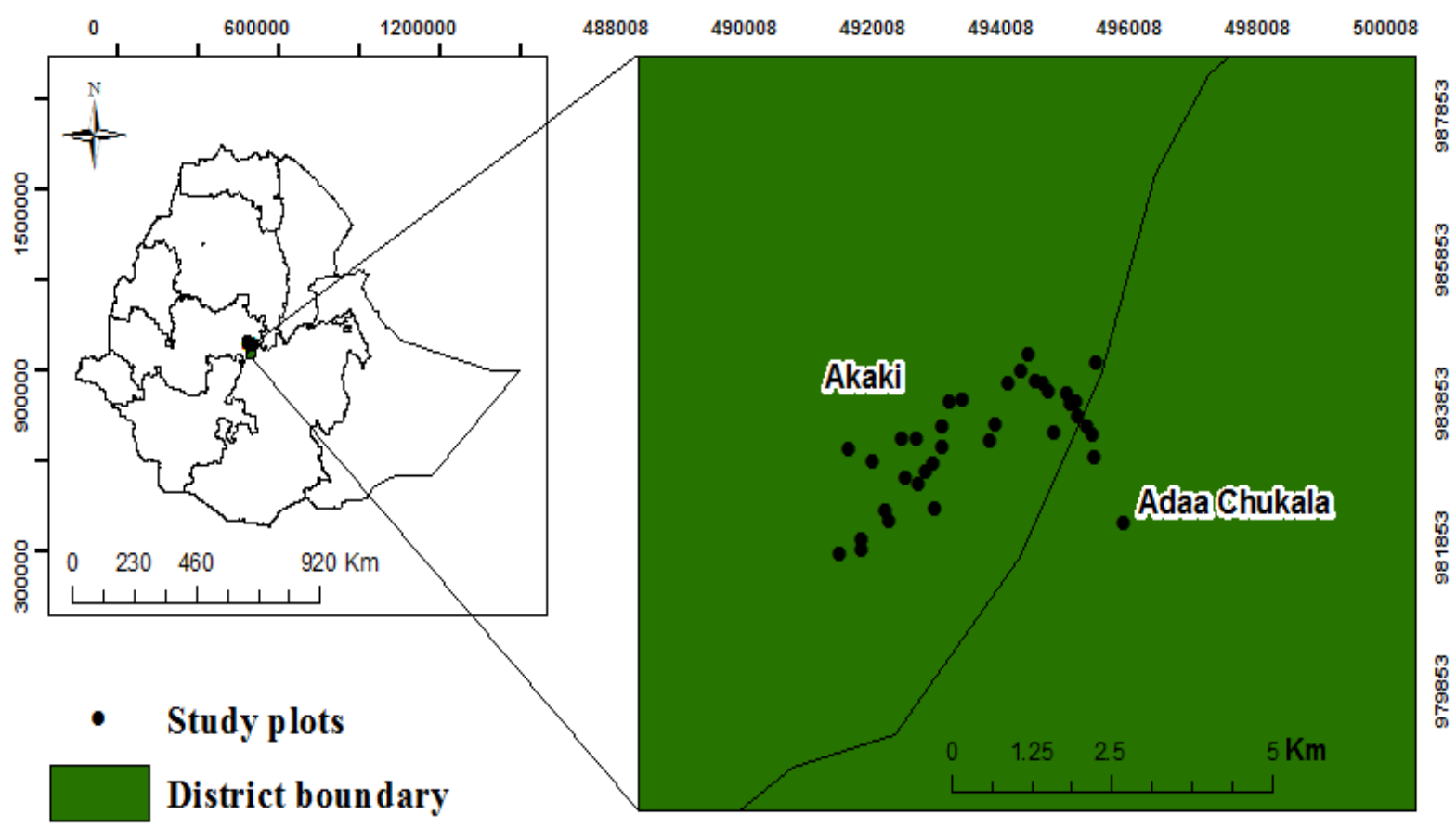

\section{Regional boundary}

Figure 1. Geographical location of the study area. 


\section{Sampling frame}

Reconnaissance survey was conducted to have an overview of the study area. Then the study area was stratified into three altitudinal ranges (Lower altitude $=2100-2400 \mathrm{~m}$, Middle altitude $=2400-2700 \mathrm{~m}$ and Higher altitude $=2700-3000 \mathrm{~m}$ ). Moreover, each altitudinal gradient was stratified into three abundance types (dense, medium and sparse stands). In a strata four quadrant $20 \times 20 \mathrm{~m}$ with a total of 36 quadrant were randomly laid down, $200 \mathrm{~m}$ apart.

Data collection and analysis

Data collection was conducted in the main plot; data such as height, Diameter at Breast Height (DBH) and height of all woody species with a height $\geq 2.5 \mathrm{~m}$ and $\mathrm{DBH} \geq 2.5 \mathrm{~cm}$ were measured in the main plot using hypsometer and calliper (Alelign et al. 2007). The canopy covers of shrubs were measured and recorded in each quadrate. Local names and scientific names were also assessed using knowledgeable people and appropriate literature in the field and Addis Ababa University herbarium, respectively.

Shrubs and sapling data collection were conducted in two subplots that laid out in the main plot. $5 \mathrm{~m} \times 5 \mathrm{~m}$ subplots established at the opposite corner of the main quadrate. Five $2 \mathrm{~m} \times 2 \mathrm{~m}$ (four at the corners and one at the center) subplots were also used to determine abundance and frequency of seedlings. Environmental data such altitude, latitude, longitude aspect and slope were taken using GPS, SUNTO compass and clinometers.

Diversity, structure and regeneration status of the woody species were analyzed following Kent (2012).

- The diversity of woody species was analyzed using species richness, Shannon's Evenness and the Shannon-Wiener diversity index (Krebs 1989, Magurran 2004).

$$
\begin{aligned}
& \mathrm{E}=\frac{\mathrm{H}^{\prime}}{\mathrm{H}^{\prime}{ }_{\text {max }}} \\
& \mathrm{H}^{\prime}=-\sum_{\mathrm{i}=1}^{\mathrm{s}} \mathrm{p}_{\mathrm{i}} \ln \mathrm{p}_{\mathrm{i}}
\end{aligned}
$$

Where; $\mathrm{E}=$ Shannon - Wiener evenness, $\mathrm{ln}=$ (natural logarithm) of number of species, $\mathrm{H}^{\prime}=$ Shannon Wiener index of species diversity, $\mathrm{p}_{\mathrm{i}}=$ proportion of individual found in the $\mathrm{i}^{\mathrm{t}}$ species.

- Species density was summarized from the total number of individual abundance in each species. Basal area for each species was analyzed using the formula: $\mathrm{BA}=\pi \mathrm{DBH}^{2} / 4$. We calculated important value index using the following equation.

$$
\begin{gathered}
\text { Relative Density }(\mathrm{RD})=\frac{\text { Number of individual of a species }}{\text { Total number of individual of species }} \times 100 \\
\text { Relative Frequency }(\mathrm{RF})=\frac{\text { Frequency of a species }}{\text { Frequency of all species }} \times 100 \\
\text { Relative Dominance }(\mathrm{RDO})=\frac{\text { Dominance of a species }}{\text { Dominance of all species }} \times 100 \\
\mathrm{IVI}=\mathrm{RD}+\mathrm{RF}+\mathrm{RDO}
\end{gathered}
$$

Where; $\mathrm{RD}=$ Relative density, $\mathrm{RF}=$ Relative frequency, $\mathrm{RDO}=$ Relative dominance

All the above analysis was conducted using $\mathrm{R}$ software program version 3.3.0 ( $\mathrm{R}$ Core Team 2016) and vegan package in $\mathrm{R}$ (Jari et al. 2016).

\section{RESULTS}

Woody species composition and diversity

Thirty-one indigenous woody species representing 23 families were recorded (Table 1). The most diverse families were Anacardiaceae, Celastraceae, Euphorbiaceae, Lamiaceae, Myrsinaceae, Rosaceae and Sapindaceae. In general, $22.6 \%$ were trees and the remaining $77.4 \%$ were shrubs. The diversity values of woody species were 2.0, 2.14 and 2.38 in the higher, middle and lower altitude range, respectively, while their corresponding evenness values were $0.67,0.74$ and 0.81 , respectively (Table 2). 
Table 1. List of only woody species recorded from Yerer Mountain with habit, density $\left(\mathrm{m}^{-2}\right)$, frequency $\left(\mathrm{m}^{-2}\right)$, dominance $\left(\mathrm{m}^{2} \mathrm{ha}^{-1}\right)$, their relative values (\%) and importance value index (IVI).

\begin{tabular}{|c|c|c|c|c|c|c|c|c|}
\hline Scientific Name & HB & D & RD & $\mathbf{F}$ & $\mathbf{R F}$ & DO & RDO & IVI \\
\hline Acacia bussei Sjostedt & $\mathrm{T}$ & 0.69 & 0.12 & 2.78 & 0.46 & 0.00 & 0.09 & 0.67 \\
\hline Allophylus abyssinicus (Hochst.) & S & 1.39 & 0.23 & 2.78 & 0.46 & - & - & - \\
\hline Radlk. & & & & & & & & \\
\hline Bersama abyssinica Fresen. & $\mathrm{T}$ & 1.39 & 0.23 & 5.56 & 0.91 & - & - & - \\
\hline Buddleja polystachya Fresen. & $\mathrm{T}$ & 6.25 & 1.05 & 16.67 & 2.74 & 0.01 & 1.37 & 5.16 \\
\hline Carissa edulis (Forssk.) Vahl & S & 84.03 & 14.15 & 63.89 & 10.50 & - & - & - \\
\hline Celtis africana Burm.f. & S & 4.86 & 0.82 & 2.78 & 0.46 & - & - & - \\
\hline $\begin{array}{l}\text { Clerodendrum myricoides (Hochst.) } \\
\text { R.Br. ex Vatke }\end{array}$ & S & 0.69 & 0.12 & 2.78 & 0.46 & - & - & - \\
\hline $\begin{array}{l}\text { Croton macrostachyus Hochst. ex } \\
\text { Delile }\end{array}$ & $\mathrm{T}$ & 2.08 & 0.35 & 8.33 & 1.37 & 0.00 & 0.27 & 1.99 \\
\hline $\begin{array}{l}\text { Dichrostachys cinerea (L.) Wight } \\
\text { \& Arn. }\end{array}$ & S & 2.78 & 0.47 & 8.33 & 1.37 & - & - & - \\
\hline Dodonaea angustifolia L.f. & S & 48.61 & 8.19 & 36.11 & 5.94 & - & - & - \\
\hline Erica arborea L. & S & 80.56 & 13.57 & 13.89 & 2.28 & - & - & - \\
\hline Euclea racemosa $\mathrm{L}$. & S & 0.69 & 0.12 & 2.78 & 0.46 & - & - & - \\
\hline Euphorbia tirucalli L. & S & 0.69 & 0.12 & 2.78 & 0.46 & - & - & - \\
\hline Grewia bicolor Juss. & S & 0.69 & 0.12 & 2.78 & 0.46 & - & - & - \\
\hline $\begin{array}{l}\text { Heteromorpha arborescens } \\
\text { (Spreng.) Cham. \& Schltdl. }\end{array}$ & S & 2.78 & 0.47 & 11.11 & 1.83 & - & - & - \\
\hline Hypericum revolutum Vahl & S & 4.86 & 0.82 & 5.56 & 0.91 & - & - & - \\
\hline Juniperus procera Hochst. ex Endl. & $\mathrm{T}$ & 111.11 & 18.71 & 72.22 & 11.87 & 0.54 & 95.07 & 125.66 \\
\hline Maesa lanceolata Forssk. & S & 1.39 & 0.23 & 5.56 & 0.91 & - & - & - \\
\hline $\begin{array}{l}\text { Maytenus arbutifolia (Hochst. ex } \\
\text { A.Rich.) R.Wilczek }\end{array}$ & S & 4.17 & 0.70 & 2.78 & 0.46 & - & - & - \\
\hline $\begin{array}{l}\text { Maytenus undata (Thunb.) } \\
\text { Blakelock }\end{array}$ & S & 46.53 & 7.84 & 50.00 & 8.22 & - & - & - \\
\hline Myrsine africana $\mathrm{L}$. & S & 54.86 & 9.24 & 52.78 & 8.68 & - & - & - \\
\hline $\begin{array}{l}\text { Osyris quadripartita Salzm. ex } \\
\text { Decne. }\end{array}$ & S & 27.78 & 4.68 & 47.22 & 7.76 & - & - & - \\
\hline Otostegia integrifolia Benth. & S & 9.72 & 1.64 & 8.33 & 1.37 & - & - & - \\
\hline Pittosporum abyssinicum Delile & $\mathrm{T}$ & 6.94 & 1.17 & 25.00 & 4.11 & 0.01 & 1.93 & 7.21 \\
\hline Prunus africana (Hook.f.) Kalkman & $\mathrm{T}$ & 1.39 & 0.23 & 5.56 & 0.91 & 0.00 & 0.18 & 1.33 \\
\hline Rhamnus staddo A.Rich. & S & 20.83 & 3.51 & 27.78 & 4.57 & - & - & - \\
\hline Rhus natalensis Bernh. ex C.Krauss & S & 32.64 & 5.50 & 44.44 & 7.31 & - & - & - \\
\hline Rhus retinorrhoea Oliv. & $\mathrm{T}$ & 8.33 & 1.40 & 19.44 & 3.20 & 0.01 & 1.08 & 5.68 \\
\hline Rosa abyssinica R.Br. & $\mathrm{S}$ & 0.69 & 0.12 & 2.78 & 0.46 & - & - & - \\
\hline Rubus volkensii Engl. & S & 23.61 & 3.98 & 52.78 & 8.68 & - & - & - \\
\hline Vernonia rueppellii Sch.Bip. ex & $\mathrm{S}$ & 0.69 & 0.12 & 2.78 & 0.46 & - & - & - \\
\hline
\end{tabular}

Walp.

Note: HB- Habit; T- Trees; S- Shrubs; D- Density; F- Frequency, DO- Dominance; RD- Relative density (\%); RF-

Relative Frequency (\%); RDO- Relative Dominance (\%).

Table 2. Summary of the diversity, richness and evenness for woody forest species in Yerer Mountain.

\begin{tabular}{lrrr}
\hline Altitude range & H & Richness & Evenness \\
\hline Higher (2700-3000) & 2.00 & 20 & 0.67 \\
Medium (2400-2700) & 2.14 & 18 & 0.74 \\
Lower (2100-2400) & 2.38 & 19 & 0.81 \\
\hline
\end{tabular}

Density, frequency and dominance

The total densities of all woody species were $595 \mathrm{stems} \mathrm{ha}^{-1}$. The most six densest species in the study area were Juniperus procera (111 stems ha $\left.{ }^{-1}\right)$, Carissa edulis $\left(84 \mathrm{stems} \mathrm{ha}^{-1}\right)$, Erica arborea $\left(81 \mathrm{stems} \mathrm{ha}^{-1}\right)$, Myrsine africana (55 stems ha ${ }^{-1}$ ), Dodonaea angustifolia (49 stems ha ${ }^{-1}$ ), Maytenus undata (47 stems ha ${ }^{-1}$ ). The total frequency of woody species in the study area was 608.3. The most frequently appeared species are Juniperus procera (11.8\%), Carissa edulis (10.5\%), Myrsine Africana (8.6\%), Rubus volkensii (8.6 \%), Maytenus undata $(8.2 \%)$ and Osyris quadripartite $(7.7 \%)$. The total dominance of woody species was $0.56 \mathrm{~m}^{2} \mathrm{ha}^{-1}$. The most dominant tree species were Juniperus procera (95.07\%), Pittosporum abyssinicum (1.93 \%), Buddleja polystachya (1.37\%), Rhus retinorrhoea (1.08\%), Croton macrostachyus (0.27\%), Prunus Africana (0.18\%), Acacia bussei (0.09\%). 


\section{Important value index (IVI)}

Juniperus procera (126), Pittosporum abyssinicum (7), Rhus retinorrhoea (6), Buddleja polystachya (5), Croton macrostachyus (2), Prunus Africana (1) and Acacia bussei (0.6) exhibited the highest important value index in the study area.

\section{Population structure and regeneration status}

The DBH class distribution of woody species was a reverse "J" shape distribution pattern (Fig. 2). There are small numbers of individuals in the first class but high number of individuals in the second class. This exhibited as stable structures. The structural analysis depicted a variation among the structure of overall community and species level (Figs. $2 \& 3$ ). The population structure of all species, except Juniperus procera, showed unhealthy and, most of the woody species had poor regeneration status, which needs conservation. The total density of seedling, sapling, shrub and trees in the study area were 6383, 1022, 481 and $115 \mathrm{ha}^{-1}$, respectively (Fig. 4).

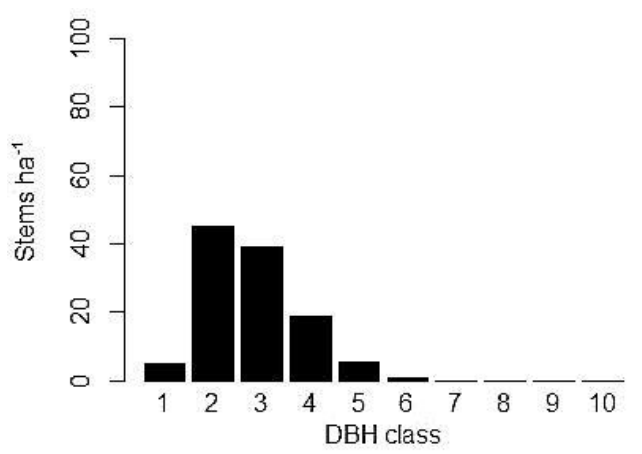

Figure 2. DBH class $(\mathrm{cm})$ distribution of overall woody species. [Class $1=<2,2=2-5,3=5-10,4=10-15,5=15-20,6=20-25$, $7=25-30,8=30-35,9=35-40,10=>40]$
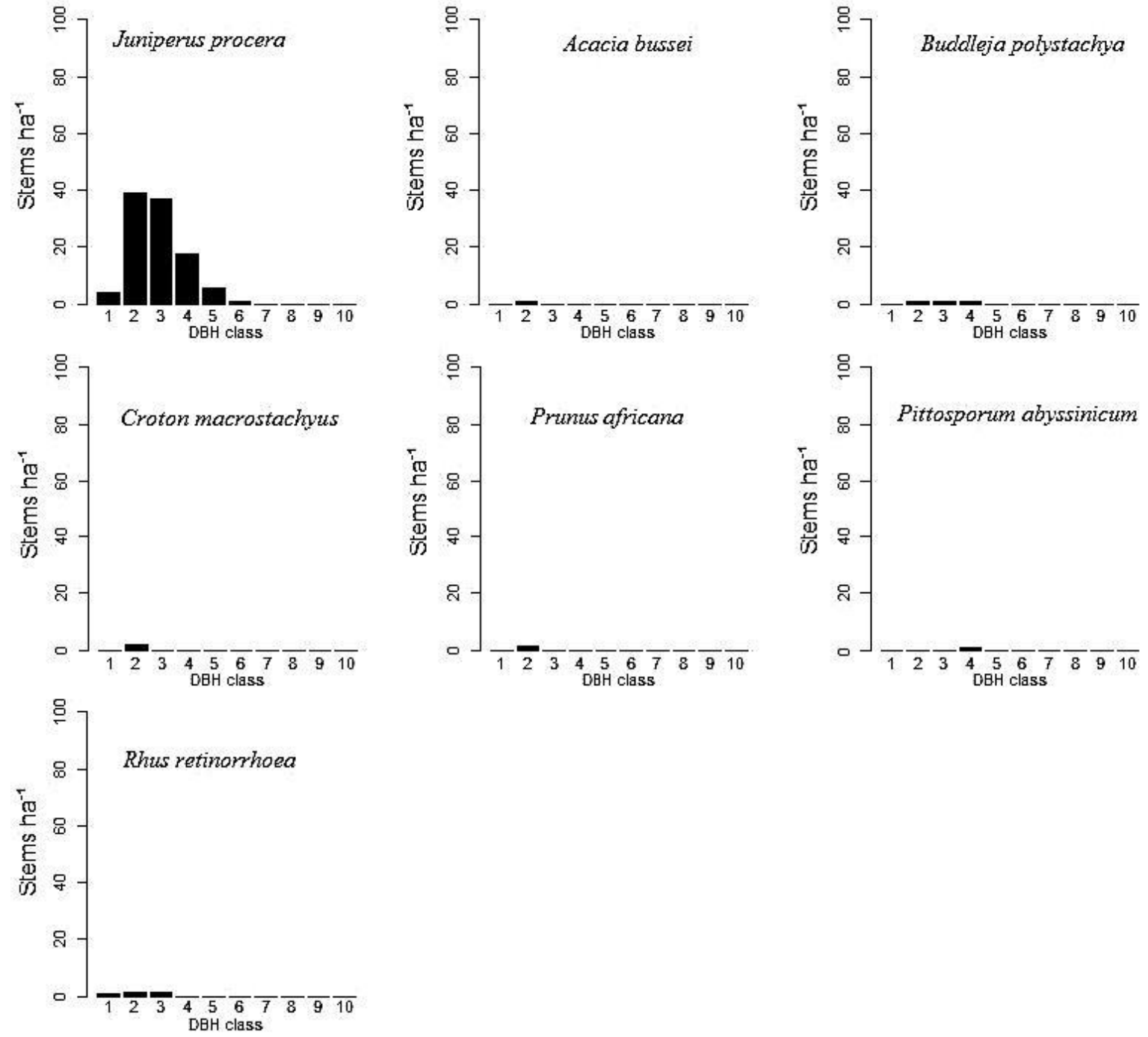

Figure 3. Population structure of dominant species. [Class $1=<2,2=2-5,3=5-10,4=10-15,5=15-20,6=20-25,7=25-30$, $8=30-35,9=35-40,10=>40]$ 


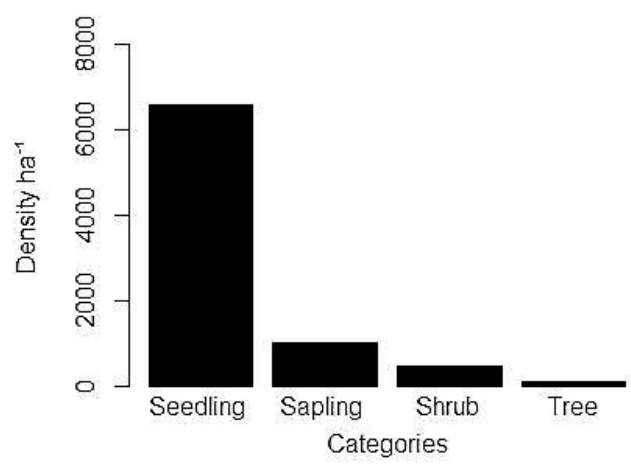

Figure 4. Density $\left(\mathrm{ha}^{-1}\right)$ of seedling sapling shrub and tree.

\section{DISCUSSION}

The study site had less woody species as compared with similar forest ecosystem in Ethiopia, namely Chilimo forest with 42 (Siraj \& Zhang 2018), Munessa-Shashemene with 56 (Senbeta et al. 2002), Kuandisha (Berhanu et al. 2016), Wof-Washa with 48 (Fisaha et al. 2013), Gara Ades with 40 and Menagesha with 41 (Teketay 1997) woody species. In present study, the number of woody species including trees and shrubs was 31 , which is relatively close to the number of woody species (39) recorded from Arero forest (Shiferaw et al. 2018). This is also evident from the relatively low value of woody species diversity.

The diversity of woody species in Yerer Mountain is lower than Chilimo forest $\left(\mathrm{H}^{\prime}=2.72\right)$ (Woldemariam et al. 2000), Zegie Peninsula ( $\left.\mathrm{H}^{\prime}=3.72\right)$ (Alelign et al. 2007), Tara Gedam $\left(\mathrm{H}^{\prime}=2.98\right)$ (Zegeye et al. 2011) and Arero forest $\left(\mathrm{H}^{\prime}=2.67\right)$ (Shiferaw et al. 2018). However, the present study had greater diversity index compared with Abebaye forest $\left(\mathrm{H}^{\prime}=1.31\right)$ (Zegeye et al. 2011). The reason might be due to the dominance of few woody species at Yerer. This is also reflected by the relatively lower value of Shannon evenness index $(E=0.74)$ in the study area as compared with that of Zegie $(\mathrm{E}=0.84)$ (Alelign et al. 2007). The study area has higher evenness as compared to Tara Gedam $(\mathrm{E}=0.65)$ and Abebaye $(\mathrm{E}=0.31)$ natural forests (Zegeye et al. 2011). Low Shannon evenness implies the existence of unbalance distribution of the individuals of species so that it needs more conservation than communities that have high value of evenness.

The present study has less density, frequency and dominance than Zegie (Alelign et al. 2007), Tara Gedam \& Abebaye (Zegeye et al. 2011) and Wof-Washa (Fisaha et al. 2013). Therefore, this also reflects the existence of selective removal of large size trees. As a result, only few woody species like Juniperus procera Hochst. ex Endl., Pittosporum abyssinicum Delile, Buddleja polystachya Fresen., Rhus retinorrhoea Oliv., Croton macrostachyus Hochst. ex Delile, Prunus africana (Hook.f.) Kalkman, Acacia bussei Sjostedt dominates the forest. Similarly, the same lists of species constitute the highest IVI as they are dominated. Juniperus procera (126), Pittosporum abyssinicum (7), Rhus retinorrhoea (6), Buddleja polystachya (5), Croton macrostachyus (2), Prunus Africana (1) and Acacia bussei (0.6) exhibited the highest important value index in the study.

The structure and regeneration status indicated the forest lied under younger secondary forest that showed restoration. According to Bekele (2000), dry Afromontane forests at early succession development establish many pioneer species and grow together in high density until they reach the climax stage. The seedlings were greater than that of sapling and shrub/mature trees. This implies that the distribution of woody species at seedling and sapling level had good regeneration.

\section{CONCLUSION AND RECOMMENDATIONS}

The Yerer Mountain forest contains thirty-one indigenous woody specie. Juniperus procera, Pittosporum abysinicum, Rhus retinorrhoea, Buddleja polystachya,Croton macrostachyus, Prunus africana and Acacia bussei are dominant tree species. The density of woody species is relatively high while the total basal area is very small. The overall community experienced stable and healthy structure (inverted J shape) and good regeneration status. Similarly, Juniperus procera shows a healthy diameter structure. Generally, the diversity and evenness of the study area imply the need to conserve and proper management of the forests from several human disturbances. We recommended intervention of forest management efforts to increase diversity and enhance natural regeneration of poorly represented species.

\section{ACKNOWLEDGEMENTS}

The authors would like to thank the Ethiopian Environment and Forest Research Institute (EEFRI) for covering the research fund. We would like also to thank all research staff of Central Ethiopia Environment and 
Forest Research Center for assisting in data collection and analysis. The anonymous reviewers are also highly acknowledged and appreciated for their valuable comments and suggestions.

\section{REFERENCES}

Addo-Fordjour P, Obeng S, Anning A \& Addo M (2009) Floristic composition, structure and natural regeneration in a moist semi deciduous forest following anthropogenic disturbances and plant invasion. International Journal of Biodiversity and Conservation 1(2): 21-37.

Alelign A, Teketay D, Yemshaw Y \& Edward S (2007) Diversity and status of regeneration of woody plants on the peninsula of Zegie, north western Ethiopia. Tropical Ecology 48(1): 37-49.

Amsalu A, Stroosnijder L \& Graaff J de (2007) Long-term dynamics in land resource use and the driving forces in the Beressa watershed, highlands of Ethiopia. Journal of Environmental Management 83(4): 448-459.

Bekele T (2000) Plant population dynamics of Dodonaea angustifolia and Olea europaea spp. cuspidata in dry Afromontane Forests of Ethiopia, (Ph.D Thesis). Acta Universitatis Upsaliensis, Uppsala.

Berhanu A, Demissew S, Woldu Z \& Didita M (2016) Woody species composition and structure of Kuandisha afromontane forest fragment in north-western Ethiopia. Journal of Forestry Research 28(2): 343-355.

Bewket W \& Abebe S (2013) Land-use and land-cover change and its environmental implications in a tropical highland watershed, Ethiopia. International Journal of Environmental Studies 70(1): 126-139.

EFAP (1994) Ethiopian Forestry Action Program (EFAP). EFAP, Addis Ababa, Ethiopia.

ENMSA (2011) Rainfall and temperature data for Yerer Mountain Forest Area (2000 to 2010). Ethiopian Meteorological Services Agency. Addis Ababa, Ethiopia.

Fisaha G, Hundera K \& Dalle G (2013) Woody plants' diversity, structural analysis and regeneration status of Wof Washa natural forest, North-east Ethiopia. African Journal of Ecology 51(4): 599-608.

Friis I, Demissew S \& Breugel PV (2010) Atlas of the potential vegetation of Ethiopia. The Royal Danish Acadamy of Sciences and Letters (Natural habitats), Addis Ababa.

Giriraj A, Murthy M \& Ramesh B (2008) Vegetation composition, structure and patterns of diversity: a case study from the tropical wet evergreen forests of the Western Ghats, India. Edinburgh Journal of Botany 65 : $1-22$.

Jari O, F. Guillaume B, Michael F, Roeland K, Pierre L, Dan M, Peter R, RB O'Hara, Gavin L, Peter S, M. Henry H, EduardS \& Helene W (2016) Vegan: Community Ecology Package. R package version 2.4-0. [https://CRAN.R-project.org/packagevegan]

Kent M (2012) Vegetation description and data analysis: a practical approach, $2^{\text {nd }}$ edition. John Wiley \& Sons, Ltd, UK.

Kibret KS, Marohn C \& Cadisch G (2016) Assessment of land use and land cover change in South Central Ethiopia during four decades based on integrated analysis of multi-temporal images and geospatial vector data. Remote Sensing Applications: Society and Environment 3: 1-19.

Kindu M, Schneider T, Teketay D \& Knoke T (2013) Land Use/Land Cover Change Analysis Using ObjectBased Classification Approach in Munessa-Shashemene Landscape of the Ethiopian Highlands. Remote Sensing 5: 2411-2435.

Krebs CJ (1989) Ecological methodology. New York: Harper Collins Publishers.

Magurran AE (2004) Measuring biological diversity. Malden and Oxford: Blackwell Publishing.

Meshesha DT, Tsunekawa A, Tsubo M, Ali SA \& Haregeweyn N (2013) Land-use change and its socioenvironmental impact in Eastern Ethiopia's highland. Regional Environmental Change 14(2): 757-768.

Mishra AK, Bajpai O, Sahu N, Kumar A, Behera SK, Mishra RM \& Chaudhary LB (2013) Study of Plant Regeneration Potential in Tropical Moist Deciduous Forest in Northern India. International Journal of Environment 2(1): 153-163.

Melaku A, Suryabhagavan KV \& Balakrishnan M (2012) Assessment of Cover Change in the Harenna Habitats in Bale Mountains, Ethiopia, Using GIS and Remote Sensing. International Journal of Ecology and Environmental Sciences 38(1): 39-45.

Pappoe AN, Armah FA, Quaye EC, Kwakye PK \& Buxton GN (2010) Composition and stand structure of a tropical moist semi deciduous forest in Ghana. International Journal of Plant Sciences 1: 095-106.

$\mathrm{R}$ Core Team (2016) R: A language and environment for statistical computing. R Foundation for Statistical Computing, Vienna, Austria. [https://www.R- project.org/]

Senbeta F \& Denich M (2006) Effects of wild coffee management on species diversity in the Afromontane rainforests of Ethiopia. Forest Ecology and Management 232: 68-74. 
Senbeta F \& Teketay D (2003) Diversity, Community types and Population Structure of Woody plants in Kimphee Forest, a virgin Nature Reserve in Southern Ethiopia. Ethiopian Journal of Biological Sciences 2: 169-187.

Senbeta F, Teketay D \& Nslund B- $\AA$ (2002) Native woody species regeneration in exotic tree plantations at Munessa - Shashemene Forest, southern Ethiopia. New Forests 24: 131-145.

Shiferaw W, Lemenih M \& Gole TWM (2018) Analysis of plant species diversity and forest structure in Arero dry Afromontane forest of Borena zone, South Ethiopia. Tropical Plant Research 5(2): 129-140.

Siraj M \& Zhang K (2018) Structure and natural regeneration of woody species at central highlands of Ethiopia. Journal of Ecology and the Natural Environment 10(7): 147-158.

Soromessa T, Teketay D \& Demissew S (2004) Ecological study of the vegetation in Gamo Gofa zone, Southern Ethiopia. Tropical Ecology 45: 209-221.

Teketay D (1992) Human impact on a natural montane forest in Southeastern Ethiopia. Mountain Research and Development 12: 393-400.

Teketay D (1997) Seedling populations and regeneration of woody species in dry Afromontane forest of Ethiopia. Forest Ecology and Management 98: 149-165.

Tesfaye G, Teketay D, Fetene M \& Beck E (2010) Regeneration of seven indigenous tree species in a dry Afromontane forest, southern Ethiopia. Flora - Morphology, Distribution, Functional Ecology of Plants 205(2): 135-143.

Woldemariam T \& Teketay D (2001) The forest coffee ecosystems: Ongoing crises, problems and opportunities for coffee gene conservation and sustainable utilization. In: Imperative problems associated with forestry in Ethiopia, Workshop proceedings. Biological Society of Ethiopia, Addis Ababa, Ethiopia.

Woldemariam T (2003) Vegetation of the Yayu forest in SW Ethiopia: impacts of human use and implications for insitu conservation of wild Coffee Arabica L. populations. Ecology and Development Series 10.

Woldemariam T, Teketay D, Edwards S \& Olsson M (2000) Woody plant and avian species diversity in a dry Afromontane forest on the central plateau of Ethiopia: Biological indicators for conservation. Ethiopian Journal of Natural Resources 2: 255-293.

Woldu Z, Dragan M, Feoli E \& Fernetti M (2002) Reducing soil erosion in Northern Ethiopia, Adwa Zone, through a special decision support system (SDSS). Ethiopian Journal of Biological Sciences 1: 1-12.

Worku A, Teketay D, Lemenih M \& Fetene M (2012) Diversity Regeneration Status and Population Structure of Gum and Resin Producing Woody Species in Borana, Southern Ethiopia. Forests, Trees and Livelihoods iFirst Article, pp. 1-12.

Zegeye H, Teketay D \& Kelbessa E (2011) Diversity and Regeneration Status of Woody Species in Tara Gedam and Abebaye Forests, North-western Ethiopia. Journal of Forestry Research 22: 315-328.

Zegeye H, Teketay D \& Kelbessa E (2006) Diversity, regeneration status and socio-economic importance of the vegetation in the islands of Lake Ziway, south-central Ethiopia. Flora-Morphology, Distribution, Functional Ecology of Plants 201(6): 483-498. 